\title{
La «ropa de la China» desde Filipinas hasta Buenos Aires. Circulación, consumo y lucha corporativa, 1580-1620
}

\author{
por \\ Mariano Bonialian \\ Centro de Estudios Históricos, El Colegio de México \\ marianobonialian@gmail.com
}

El ensayo explora el comercio y el consumo de telas asiáticas que circularon desde Acapulco hasta Buenos Aires entre 1580 y 1620. A partir de la consulta de las fuentes ubicadas en el Archivo de Indias, como son los informes de virreyes, gobernadores y de comerciantes, se demuestra que el comercio de «ropa de la China» constituyó una pieza fundamental de un modelo comercial alternativo al oficial; en el cual México desafiaba la centralidad económica peninsular.

Palabras Clave: comercio; consumo; textiles chinos; México; Río de La Plata; 1580-1620.

\section{INTRODUCCIÓN}

La historiografía hispanoamericana de las últimas décadas se ha ocupado de otorgarle un papel clave al contrabando en la comprensión del funcionamiento de la «Carrera de Indias» ${ }^{1}$. El fenómeno llega a caracterizarse como la más fiel expresión de la temprana autonomía política de los virreinatos, de la diversificación de sus estructuras económicas y del auge del comercio intercolonial, en particular el que se edifica desde finales del siglo XVI en torno a México, Perú y Filipinas ${ }^{2}$. El consenso es

\footnotetext{
1 Moutoukias, 1988; 1991: 333-368. Malamud, 1986.

2 Romano, 1993; 1998. 
pleno entre los historiadores al concebir el contrabando como una de las herramientas más contundentes para desacreditar la idea de un aparente declive del comercio trasatlántico de flotas en el siglo XVII ${ }^{3}$. Al mismo tiempo contribuye a pintar un cuadro bastante alejado del apuntado por las clásicas obras de la historiografía económica las que, con una perspectiva atlántica-peninsular y con la aplicación de una metodología cuantitativa del comercio legal entre España y América, ofrecen una interpretación parcial sobre el comercio de ultramar por la Monarquía ${ }^{4}$. Con todo, el contrabando también presenta importantes limitaciones como variable analítica para una interpretación más integral de la economía colonial. Es que habría que partir de la premisa que no todo fenómeno comercial pasa por la línea de oposición legalidad-contrabando. La «desviación» de caudales y bienes por fuera de la órbita o del monitoreo peninsular no transita necesariamente por la vía del contrabando.

El presente ensayo formula un caso que escapa tanto a un estudio exclusivo del contrabando como a los circuitos legales de comercio. Se analiza la circulación y el consumo de la «ropa de la China» por los mercados de Hispanoamérica entre las décadas que van de 1580 a 1620. El fenómeno constituye una pieza fundamental de un sistema comercial alternativo al oficial que llega a combinar flujos legales e ilícitos por el imperio español. Es que los textiles que llegan desde la China al puerto de Acapulco a través del reconocido galeón de Manila se distribuyen por el Perú e incluso por las plazas mercantiles de Chile y Buenos Aires ${ }^{5}$. En un trabajo del año 2011 ofrecí los lineamientos generales del papel adquirido por el «comercio de la China» en el monopolio comercial para el período comprendido entre 1680 y $1740^{6}$. Allí intenté demostrar que el tráfico asiático representa una pieza clave de un modelo comercial imperial cuya centralidad se situaba en la

${ }^{3}$ Un comentario aparte merece la obra de Morineau en la que, entre otras brillantes ideas, se demuestra que aún si se refiere a canales legales, las llegadas de plata a España y Europa durante la segunda mitad del siglo XVII, lejos de disminuir, alcanzan niveles elevados con respecto a etapas previas. Morineau, 1985.

${ }^{4}$ No es mi intención presentar una bibliografía completa. Me limitaré a mencionar los que a mi juicio son los trabajos más representativos de la corriente: Hamilton, 1975. Chaunu, 1955-1959. García Fuentes, 1980. García Baquero, 1976.

${ }^{5}$ La historiografía sobre el galeón de Manila es extensa. Aquí menciono los más representativos. Schurz, 1939. Chaunu, 1955-59. Flynn y Giráldez, 1997. Yuste, 1984; 2007. Alfonso Mola y Martínez Shaw, 2000. Bernal, 2004: 485-525. En lo que respecta al comercio asiático desde México al Perú: Schurz, 1918: 389-402. Borah, 1975. Ramos, 1970. Navarro García, 1965: 11-55. Bonialian, 2012. Por lo consultado, no hay estudios para el caso de Buenos Aires y Chile.

${ }^{6}$ Bonialian, 2011: 7-27. 
Nueva España. El espacio del Perú, más que inclinar su capital hacia Portobelo, participa en ese tejido en una relación de dependencia con el puerto novohispano de Acapulco, al ser éste una vía principal de abastecimiento de mercaderías chinas y europeas para sus mercados consumidores. La conclusión ofrecida en esa oportunidad daba cuenta que el flujo intercolonial por el mar del Sur se convierte en un factor operante para: a) la vitalidad del eje novohispano trasatlánticos de las flotas y del corredor transpacífico y b) como tendencia opuesta, el declive y la definitiva anulación en 1740 de los galeones y las ferias de Portobelo. La presente comunicación extiende esas líneas de interpretación para un período más temprano. Me aproximaré al estudio de la circulación y el consumo de ropa china partiendo de la premisa que el modelo con epicentro en México - que cuestiona la centralidad peninsular- ya funciona con plenitud hacia finales del siglo XVI. Gran parte de la responsabilidad de lo que sería la «primera crisis» del régimen comercial monopólico con centro en Portobelo de las primeras décadas del siglo XVI llega por el funcionamiento de este tejido mercantil, cuyos efectos, incluso, llegan a sentirse hasta la ciudad de Santiago de Chile y el «joven» puerto atlántico de Buenos Aires.

De manera que, el ensayo contribuye con al menos dos corrientes historiográficas que vienen cobrando carta de naturaleza durante la última década. Por un lado, la revalorización de las relaciones comerciales transpacíficas dentro del escenario del imperio español, donde aún sigue predominando una visión atlantista del Pacífico al ser colocado como un suceso marginal o como una simple prolongación del devenir económico europeo. Por otro lado, se inscribe en una interpretación historiográfica que tiende a realzar el papel de la Nueva España en las relaciones coloniales, jerarquizando, con gran cuota de autonomía con relación a las instituciones metropolitanas de gobierno, su influencia con otros espacios, particularmente con las islas Filipinas, Centroamérica y el Perú.

El ensayo consta de tres apartados. En el primero, expongo el derrotero de la «ropa de la China» que va desde el puerto de Acapulco hasta alcanzar el puerto atlántico del Río de La Plata. Seguidamente analizo los mercados por donde se intercambia y consume la ropa de China. En el segundo apartado explicito la lucha que suscita «la contratación de la China» entre los grupos corporativos del comercio de Perú y de Sevilla; el primero con vistas a potenciar su trato como una alternativa al lento y costoso suministro de tejidos procedentes de Europa y los segundos para restringir o aún prohibir una contratación que no pase por su control y beneficio. En el último apartado, concentro la atención en la cultura consumidora que se configura en torno a las telas y tejidos de la China. 
Valdría anticipar con qué tipo de fuentes me aproximo al fenómeno. Me apoyo sobre fuentes cualitativas de carácter institucional. Me refiero a informes o memoriales elaborados por agentes peninsulares con algún tipo de cargo económico o político, por instituciones corporativas como el Consulado de Sevilla, del Perú, por autoridades políticas y religiosas coloniales como virreyes, gobernadores, funcionarios de la Real Hacienda y obispos. Por supuesto que estos documentos tienen su atributo, pero habría que reconocer sus limitaciones. Brindan una imagen parcial del problema, en tanto relato subjetivo, donde los argumentos tienen una clara relación con los intereses que protegen. De manera que las conclusiones que aquí se presentan requerirán de un nivel mayor de verificación con evidencia cuantitativa ${ }^{7}$. De todas maneras, estoy convencido que la evidencia documental que aquí presento resulta sugerente para situarnos lo más cerca posible a la problemática del comercio y el consumo de la «ropa de la China» por Hispanoamérica.

\section{La «ropa de la China»: desde México hasta Chile y Buenos Aires}

El 6 de mayo de 1605 el obispo de Buenos Aires, Martín Ignacio de Loyola, le comunica a Felipe III que, aun con las distancias geográficas existentes, las telas procedentes de China que se movilizan desde México hacia el Perú se consumen por los mercados de la Gobernación del Tucumán y Buenos Aires ${ }^{8}$. En una suerte de ejercicio comparativo, Loyola dice que es exagerado culpar a Buenos Aires como punto clandestino en la importación de mercaderías por parte de los mercaderes portugueses, cuando lo que «entra de China por El Callao desde Acapulco» circula por el puerto porteño. Sus itinerarios previos por el mundo le permiten explicar los problemas «temporales» rioplatenses desde una perspectiva planetaria, considerando lo que acontece por todo el horizonte de la Monarquía ${ }^{9}$. Si la «conexión china» que va de México hasta

${ }^{7}$ La consulta de inventarios post-mortem resultará un camino metodológico obligado de futuras investigaciones ya sea para confirmar o relativizar las ideas de este ensayo.

${ }^{8}$ Que se tripliquen los despachos tocantes a la contratación con las Filipinas y a la mercadería y ropa de la China que se prohíben en el Perú, 6 de mayo de 1605, Archivo General de Indias, Sevilla (AGI), Charcas, leg. 135, s/n de exp.: 1.

9 Resulta asombroso notar el itinerario que hace Loyola en sus dos vueltas al mundo. En su primer viaje planetario visita, entre otros lugares, Las Antillas, Santo Domingo, Cuba, México, Veracruz, ciudad de México, Acapulco, Filipinas, Macao, Cochinchina, Ceilán, Goa, Madagascar, Cabo de Buena Esperanza, Guinea, Lisboa. En su segundo viaje llega a Cantón, Japón, California, Acapulco, México, Veracruz, España, Panamá, Perú, Paraguay, Chile y Buenos Aires. Molina, 1953: 21-71. Loyola, 1989, 1-103. 
Buenos Aires continúa funcionando, habrá consecuencias desastrosas para el Imperio, pues siendo «grande la independencia que se va siguiendo al Perú y México de España, llegará el momento en que las Indias no estuvieren pendientes de España en todo» ${ }^{10}$.

Me resulta importante resaltar la percepción universal contenida en las reflexiones del obispo porteño porque asocian sucesos mercantiles que suceden en el espacio rioplatense con otras realidades que, en teoría, se limitan a la rada novohispana ${ }^{11}$. Un fenómeno en apariencia tan marginal como es la circulación de telas, sedas y tejidos de China por Hispanoamérica tiene la capacidad, desde tiempos tempranos, de discutir la centralidad geopolítica imperial de España. Si el sistema bipolar trasatlántico de flotas y galeones busca ubicar a la Península Ibérica como la «médula» del tejido, estableciendo relaciones directas con ambos virreinatos, el comercio de telas asiáticas con epicentro en México le revela al monopolio los altos costos y los desafíos económicos que deberá superar. En otros términos, la importación y el consumo de telas chinas por los espacios hispanoamericanas, con el consecuente drenaje de plata hacia el Oriente, trastocan los principios básicos del sistema comercial: la canalización de la plata americana y que la Península se coloque como la única vía de abastecimiento y consumo exclusivo de productos europeos hacia América. Loyola se convierte en un verdadero visionario al decir que México y Perú lograrán una «independencia» mercantil con respecto a España. Es que se está anticipando a un gran problema cuyos efectos concretos se sentirán hacia mediados del siglo xVIII, momentos en que el comercio entre México y Perú por el mar del Sur, donde la «contratación de la China» tendrá un papel central, se convierta en un razón fundamental para la crisis terminal del régimen de ferias y galeones por Portobelo y la inauguración del eje EspañaSudamérica por el Cabo de Hornos ${ }^{12}$.

La centralidad novohispana en la red mercantil imperial se manifiesta desde las últimas tres décadas del siglo XVI. Son tiempos en que por el virreinato confluyen los tres circuitos comerciales más importantes de la Monarquía hispánica: la «Carrera filipina» de Acapulco, las flotas españolas de Veracruz y el comercio intercolonial por el mar del Sur con el Perú. El dominio

${ }^{10}$ AGI, Charcas, 135, s/n de exp.: 1.

11 Según el breve ensayo de Lejarza, por esos años Loyola escribe un documento titulado "Discurso muy precioso del obispo del Río de La Plata fray Martín Ignacio de Loyola en que declara el remedio que se debería poner para el comercio de las Islas Filipinas y Nueva España y que lo que el Consejo de Indias había hecho por lo respectivo a Buenos Aires había sido de gran acierto". Es muy posible que sean las mismas reflexiones que aquí se citan. Lejarza, 1947: 50 .

12 Bonialian, 2011: 7-27. 
efectivo de España, sin un contacto directo con las islas Filipinas ni con el Oriente, se constriñe a los específicos marcos de las flotas trasatlánticas ${ }^{13}$. En este contexto general, si nuestro propósito es rastrear las telas y sedas de China que circulan y se consumen por los mercados de Hispanoamérica hay que atender, como punto de partida, el comercio de importación del galeón de Manila. Durante la segunda mitad del siglo XVI, el tráfico entre Filipinas y la América colonial corre sin restricciones y con plena libertad ${ }^{14}$. Hasta 1593, no existe una legislación que estipulara un tope sobre el volumen ni la calidad de las mercancías o de la cantidad de plata que debe movilizarse por el Pacífico. Si bien en los años 1582, 1587 y 1591 se expiden reales cédulas prohibiendo el comercio de ropa china hacia el Perú ${ }^{15}$, los mercaderes de Guatemala y de Lima seguirán enviando sus barcos hacia China y Filipinas desde diferentes puertos del Pacífico ${ }^{16}$.

Ante una «contratación de la China» que muestra señales de contraer el desarrollo del comercio trasatlántico, en 1593 la Corona confecciona un cuerpo legislativo, una definitiva regulación, para un exclusivo contacto entre Filipinas con el puerto de Acapulco ${ }^{17}$. La desmonetización de la carrera de Portobelo y la dificultad de vender las mercaderías europeas en las ferias americanas del Atlántico obligan a establecer normativas con marcado tinte regulatorio y prohibitivo. En una de ellas se margina a Perú, Panamá y Guatemala de la «contratación filipina». Sólo la Nueva España tendrá derecho para un intercambio regulado con el Oriente ${ }^{18}$. La disposición de 1593 hace mención también a un problema central que afecta el despacho de los textiles europeos

13 Recordemos que España recién podrá cumplir el sueño de un tráfico directo con el Oriente a partir de 1784, con la creación de la Real Compañía de Filipinas. Díaz Trechuelo, 1965.

${ }^{14}$ La investigación de Álvarez da cuenta que en el año 1586, en tiempos del mandato del virrey marqués de Villamanrique, la Corona decide la suspensión del tráfico entre la Nueva España y Filipinas. Pero en sólo unos días la prohibición se habría levantado. Álvarez, 2013: 45-55.

15 Consulta del Consejo de Indias, AGI, Indiferente, leg. 742, exp. 207, fols. 1-2. Schurz, 1918: 389-402. Ramos, 1970: 229.

${ }^{16}$ En efecto, durante las últimas tres décadas del siglo XVI algunas embarcaciones solicitan permiso para realizar el trayecto de un comercio directo entre Cantón o Filipinas y el Perú o Guatemala, no considerando la escala del puerto de Acapulco. Muchos de los barcos logran realizar los siguientes derroteros: China-El Callao, El Callao-Filipinas y Filipinas-Huatulco. AGI, Guatemala, leg. 41, exp. 52: 1-4. Petición de informe sobre el comercio entre Filipinas y Perú, 1582, AGI, Filipinas, leg. 339, exp. 1: 211. Carta del virrey conde de La Coruña, 1582, AGI, México, leg. 20, exp. 81: 8. Consúltese también: Iwasaki Cauti, 1992.

17 Álvarez, 2013: 25-84. Yuste, 2013: 86-106.

18 Real Cédula prohibiendo el comercio de las Indias Occidentales con las islas Filipinas, AGI, Filipinas, leg. 339, exp. 2: 72-73. Álvarez, 2013: 67-68. Yuste, 2013: 90. 
por Veracruz y Portobelo: «que no se pueda llevar la ropa de la China al Perú ni a Tierra Firme ni a otra parte de las Indias $\gg{ }^{19}$.

Ahora bien, ya sea en momentos de libre contratación o posterior a 1593, la entrada de telas orientales a México supera el nivel de consumo de sus mercados internos. Es que su importación responde no sólo a los pedidos del mercado novohispano, sino también a las necesidades de consumo de otras plazas de Hispanoamérica ${ }^{20}$. Resulta difícil comprender que el comercio exclusivamente legal de la nao de China llegue a suministrar la demanda de numerosos y tan distantes mercados. Más bien deberíamos invertir el razonamiento: que en estas décadas el fraude resulta frecuente con la connivencia de los funcionarios. Los testimonios sobre la irradiación de la «ropa de la China», aun por las plazas más remotas, abundan. En 1595, dos años después de la reglamentación, el fiscal de la Audiencia de Panamá, Francisco de Alfaro, le informa al Consejo:

...que en lo que toca a la causa de la ropa de China [...] fueron dadas por libres pues los cargadores probaron no saberse en la prohibición de Guatemala la cédula de la prohibición. También he visto información de otro pleito de que en Cartagena no hay esta cédula y allí se lleva libremente ropa de China ${ }^{21}$.

Después de 1593, la «ropa de la China» continúa circulando y consumiéndose en Guatemala. «Se lleva libremente» el textil oriental a Cartagena; verdadero «bastión» del monopolio español con los arribos del galeón de Portobelo. En los primeros años del siglo XVII, el gobernador de Panamá, Francisco Valverde de Mercado, dice que grandes porciones de los cargamentos que entran por Acapulco se reexpiden hacia Panamá, Quito, Lima y Veracruz. Pero su movimiento no finaliza ahí: desde el puerto atlántico novohispano se

19 Ibidem: 73-74.

${ }^{20}$ Reales Cédulas sobre comercio y toneladas, 1604-1620, AGI, Filipinas, leg. 43, exp. 1. Documentos sobre el comercio de Filipinas, 1602, AGI, Filipinas, leg. 35, exp. 47. Ordenanza Nueva que se hizo en razón de la navegación de la carrera de Filipinas, 1602, AGI, México, leg. 25, exp. 20: 30-45. El trabajo de Álvarez pone de manifiesto que en las últimas dos décadas del siglo XVI el volumen del tráfico del galeón se incrementa notoriamente, llegando a multiplicarse casi por 20 con respecto a décadas antecedentes. Posiblemente este crecimiento sea una señal de la enorme demanda consumidora americana. Álvarez, 2013: 25-71.

${ }_{21}$ Carta de Francisco de Alfaro, fiscal de la Audiencia de Panamá, 1596, AGI, Panamá, vol. 14, reg. 12, exp. 83: 1-2. Otro informe de 1610, también hace referencia a la entrada de ropa China a Cartagena: AGI, Panamá, vol. 16, reg. 2, núm. 23: 14. Por estos años, la llegada ilegal a las costas de Guatemala del navío La Urca procedente de Nueva España «cargada con ropa de la China» hace que el fenómeno tome conocimiento público. Respuesta al fiscal de la Audiencia de Panamá, 1595, AGI, Panamá, vol. 229, leg. 1: 114-115. 
vuelven a embarcar, vía mar del Norte, a Cartagena y Portobelo ${ }^{22}$. En 1606, el propio virrey novohispano, el marqués de Montesclaros, reconoce lo imposible de regular el tráfico de la «carrera de filipinas», cuando la «mucha ropa de China que entra en este reino de México» es un excedente que «no tiene otra salida» que Perú ${ }^{23}$. En definitiva, como diría Valverde de Mercado, México no se contenta con una «honesta limitación» que responda a la demanda de su propio consumo interno ${ }^{24}$.

Quisiera extender el análisis de la «ropa de la China» en el contexto general de las importaciones novohispanas. Es que desde muy temprano la Nueva España se convierte en el principal almacén de las telas y los tejidos extranjeros: no sólo de las que llegan desde el Oriente sino también las que arriban con la flota española. La ropa de China que alcanza a reexpedirse hacia el Perú por el mar del sur representa un problema gravísimo para España porque México asume el papel de proveedora de mercancías extranjeras hacia el mercado centroamericano y peruano. En otros términos, la reiterada violación a la regulación no es un problema que sólo apunte a la «contratación filipina». También consideran los volúmenes de mercaderías europeas y castellanas que arriban al puerto atlántico veracruzano en las flotas españolas. Parte de la canasta de mercaderías europeas que llega por el atlántico novohispano se reexporta, acompañando la «ropa de la China», por el mar del Sur hacia el Perú. Vale mencionar algunos testimonios. En 1596, el oidor de Panamá, Salazar, denuncia que el Perú «se provee de las mercaderías de las flotas de Veracruz que le faltan» y cuando el galeón de tierra firme llega a Portobelo, «está ya con abundancia de que había menester por dicha otra vía» ${ }^{25}$. El problema viene arrastrándose desde décadas anteriores. En los años 1589 y 1593, año de la real disposición de prohibición, el Cabildo de la ciudad de México denuncia que los comerciantes de Lima se internan en el virreinato novohispano para comprar telas y tejidos de Europa, provocando

${ }^{22}$ Dice Valverde en 1610: «el interés de las ganancias corrompe las leyes y ordenanzas y hace que esto no se guarde, sino que esté en peor estado que al principio. El Perú todo lleno de ropa de China, Cartagena, Portobelo recibiendo las manifestaciones de estas mercaderías habiendo tiendas públicas en ella»; AGI, 6 de octubre de 1610, Panamá, vol. 16, reg. 2, núm. 23: 14. Consúltese también las siguientes cartas enviadas a España por Valverde: AGI, 9 de octubre de 1605, Panamá, vol. 15, reg. 6, núm. 52: 4. AGI, 6 de Agosto de 1606, Panamá, vol. 15, reg. 7, núm. 75: 5. AGI, Junio de 1607, Panamá, vol. 15, reg. 8, núm. 87: 1.

${ }_{23}$ Carta del virrey marqués de Montesclaros, 1606, AGI, México, vol. 26, núm. 97: 9.

${ }^{24}$ Carta del Gobernador de Panamá, Francisco Valverde, 1607, AGI, Panamá, vol. 15, reg. 8, núm. 87: 1. Para consultar otras evidencias sobre el tema véase: Schurz, 1918: 389-402. Ramos, 1970: 220-240. Navarro García, 1965: 18-23.

${ }^{25}$ Carta del oidor de Panamá Salazar, 1596, AGI, Panamá, vol. 14, reg. 12, núm. 74: 3-4. 
un escenario de escasez y carestía en el mercado ${ }^{26}$. En un informe de 1610 firmado por los grandes mercaderes del Perú se reclama la anulación de la disposición de 1593 y la consecuente apertura del tráfico con Nueva España. Una autoridad española que no presenta su nombre trascribe el siguiente comentario del manuscrito:

Aunque es verdad que en sus cargazones traen [al Perú] mercaderías de la China de las que llegan a aquel reino de Nueva España, la mayor parte de la ropa que compran es de la de España de la que les va de acá [España] para aquél reino $\left[\right.$ México] ${ }^{27}$.

Los comerciantes de Lima reconocen la importación de la «ropa de la China» a sus mercados, pero aquí se resalta la movilización de las mercaderías castellanas y europeas en el trayecto por el mar del Sur, aun superando, según el testimonio peninsular, el flujo de los artículos asiáticos. La ausencia de costos impositivos por el Pacífico y el precio que registran las mercaderías europeas en la Nueva España -esas mismas mercaderías que los comerciantes limeños y quiteños deberían adquirirlas en Portobelo- contribuyen a que el comercio del Perú priorice el derrotero por el mar del Sur. Se puede rastrear la problemática desde el ángulo inverso del tejido comercial, es decir, a partir de la llegada de la plata peruana a México como forma de pago del textil oriental, europeo y castellano. Si estos productos que viajan desde México hacia el Perú por el Pacífico no son sólo del Oriente, se puede entonces esperar que no todo el metálico peruano que ingresa a la Nueva España viaje hacia China. En otros términos, es posible suponer que una porción considerable del metálico andino estaría internándose en el virreinato novohispano para su reexpedición por el circuito trasatlántico español. Las palabras que brinda el virrey novohispano Luis de Velasco hacia 1608 dan cuenta del complejo circuito que toma la plata peruana por México y el tipo metálico que sale hacia China y España:

...las barras de plata venden aquí los del Perú parte a los que labran moneda en esta casa donde pagan sus derechos y parte a mercaderes de esta ciudad que las envían por granjería a España para sus empleos, que les es mejor que no enviar Reales [...] por lo que cesa lo que algunos han querido decir que muchas de ellas se envían a las islas Filipinas que no es así que aquí hay barras de plata en la tierra

\footnotetext{
${ }^{26}$ Navarro García, 1965: 19. Valle Pavón, 2005: 220-227.

${ }^{27} \mathrm{La}$ bastardilla es mía. Informe de una propuesta de los mercaderes de la Ciudad de los Reyes, 1610, AGI, Filipinas, vol. 35, leg. 47: 825.
} 
que poder enviar si conviniese. Pero mejor se hallan y se entienden con reales los chinos que no con plata en pasta ${ }^{28}$.

La moneda peruana va hacia China; el metálico peruano no labrado, ya sea en pasta o en barra, que llega a México se deposita en la Casa de la Moneda y en manos de los mercaderes de la ciudad se despacha hacia España en los viajes de las flotas españolas. Es en este contexto amplio de interpretación en donde se debería integrar el análisis del comercio de la «ropa de la China». Tal es la gravitación del brazo comercial por el mar del Sur que viene a repercutir de dos formas en el monopolio trasatlántico: potencia el comercio trasatlántico de las flotas llegadas a Veracruz porque bienes y metales que circulan por su conducto pertenecen al mercado del Perú y contribuye al abandono de los intercambios en las ferias de Portobelo ante el arribo del galeón de «tierra firme». No es casual que aquella cita de Francisco Valverde de una «honesta limitación» del comercio novohispano apuntara a «todos»los canales de importación, no sólo al galeón de Manila. La legislación debería combatir no sólo al comercio de la «ropa de la China» sino al conjunto de mercaderías que fluyen por el contacto intercolonial por el Pacífico. Sólo así «los vasallos que viven en Lima podrán a encaminar sus contrataciones con seguras ganancias por el camino ordinario de Portobelo» ${ }^{29}$. Me resulta importante advertir el escenario amplio en el cual se inscribe el flujo de ropa China hacia Perú porque nos permite comprender con hondura el pensamiento del obispo Loyola en torno a la «independencia», a la autonomía mercantil, que viven México y Perú con relación a España.

Retomo el caso de las telas del Oriente para interrogarnos, en un principio, por el significado de la noción «ropa de la China» que aparece de manera recurrente en los documentos. En los últimos veinte años del siglo XVI, se produce un cambio significativo en la composición de los productos comercializados por el galeón de Manila. De unas bodegas que contienen casi la mitad de exportaciones autóctonas de Filipinas (mantas de algodón, canela, clavo pimienta, cera y especiería) se pasa a un predominio en las exportaciones de productos originarios de China en donde la seda y la loza ocupan

${ }^{28}$ Carta del virrey Luis de Velasco, el joven, 1608, AGI, México, vol. 27, núm. 66: 6. Una interpretación similar la ofrece la Audiencia de Panamá: «la plata que solía pasar por aquí para España se divide y divierte para a la China y parte a la Nueva España», Descripción de Panamá y su provincia; sacada de la relación que por mandado del Consejo hizo y envió aquella Audiencia, 1607, reproducido en Colección de Libros y documentos..., 1908: 176.

${ }^{29}$ AGI, Panamá, vol. 15, reg. 8, núm. 87: 1. 
prácticamente todos los rincones del galeón ${ }^{30}$. La utilización de aquel término se explica porque la gran mayoría de los bienes que entran por Acapulco son sedas de China. En este rubro se destacan la cruda, la de mazo y la de rollo; todas dispuestas para la elaboración de tejidos en los obrajes novohispanos. La diversidad de sus tipos es asombrosa: rasos, terciopelos, damascos, saya sayas, muselinas, el pequín, tafetanes y gorgoranes. En segundo orden, ingresan las prendas u otros tejidos de China ya confeccionadas como las batas, el quimón, medias, pañuelos y cintas de seda ${ }^{31}$.

La importación como materia prima o insumo primario de la seda china tiene su explicación. En el transcurso del siglo Xvi el cultivo de seda en el propio virreinato novohispano es impulsado desde la Corona, alcanzando su producción niveles espectaculares en la región de la Mixteca ${ }^{32}$. Pero a partir de 1580 la conveniencia de importar seda cruda contribuye a una disminución de la producción local. Su ingreso se torna más intenso cuando en 1596 la Corona le prohíbe al virreinato el cultivo de la morera ${ }^{33}$. Para entonces el desarrollo del obraje novohispano es elocuente: según los datos que brinda el virrey Montesclaros, hacia el año 1604 existen más de 110 obrajes en toda la Nueva España, con un número de trabajadores que rondan en promedio entre 50 y 100 en cada centro manufacturero ${ }^{34}$. El funcionamiento del obraje textil novohispano dependerá, cada vez más, de las importaciones de seda china venidas en el galeón de Manila. La seda mixteca no sólo se ve imposibilitada por sí sola de responder a los pedidos del mercado consumidor novohispano sino que tampoco tiene la capacidad de abastecer la demanda del mercado peruano, el que si bien constituye, por entonces, un espacio autosuficiente, requiere de dos necesidades principales: lino y seda ${ }^{35}$. No debería extrañarnos que, décadas después, en 1637, en uno de los tantos informes que envían los mercaderes peruanos y novohispanos solicitando la reapertura del comercio asiático por el triángulo de Filipinas, México y Perú, se subraye que la prohi-

${ }^{30}$ Cito aquí los cálculos que ofrece el excelente estudio de Álvarez. En 1581, las mercancías procedentes de China representan el 51,9\% de la carga de la nao, mientras que la de Filipinas llegan al 48,1\%. En 1595 las de China alcanzan el 91,8\% mientras que las del archipiélago tan sólo rondan el 8,2\%. Álvarez, 2012: 39-71.

31 AGI, Quito, vol. 170, exp. 1: 224-256.

32 Schurz, 1918: 393-394.

33 Pérez Herrero, 1983: 109.

${ }^{34}$ La lista detallada: México: 25 obrajes de paños y 10 de sombreros; Escapucalco: 2 de paños; Tlaxcala: 7 de paños, 4 de sayales y 2 de trapiches; Tepeaca: 5 de sayales; Puebla: 35 de paños; Cholula: 6 de paños; Tezcuco: 8 de paños; Sarchimilco: 4 de sayales; y Zayala: 4 de sayales, en Relación de los obrajes que se encuentran en el reino de Nueva España por el Virrey, 10 de mayo de 1604, AGI, México, vol. 26, núm. 19: 19-21.

35 Assadourian, 1982: 131-221. 
bición de comercializar «ropa de la China» desde México al Perú hace peligrar los puestos de trabajo de 14 mil personas dedicadas a la actividad textil en México $^{36}$. Este problema es fundamental porque explicita tres fenómenos: a) que el comercio de telas y sedas de la China está en íntima relación con la evolución de la producción textil novohispana; b) que constituye un elemento fundamental para el valor agregado de los productos manufacturados en la Nueva España; c) que una porción de los que se elaboran y circulan por Hispanoamérica contienen al menos un insumo de tela asiática, lo que hace que las autoridades tengan dificultades para su identificación y posible sanción ${ }^{37}$.

Ahora bien, a pesar que las leyes de prohibición se vuelven a publicar y distribuir por todo el Orbe indiano, en 1602 y 1604, las plazas del espacio sudamericano continúan con su intercambio. En 1610, el propio Francisco de Valverde, dice que «la ciudad de Lima como las demás partes están llenas de mercaderías de China en tiendas públicas». Los valles andinos disponen de las telas del Oriente por el arribo de embarcaciones que vienen de México por «donde se distribuye al distrito y ciudad de Quito, a la gobernación de Popayán, Yagualsongo, Piura, Saña y Trujillo» ${ }^{38}$. En la primera década del siglo XVII la ciudad de Quito está colmada de ropa china. El presidente de la Audiencia, Miguel de Ibarra, le informa al rey lo difícil que es cumplir con la prohibición en razón de la enorme cantidad de telas de China que circula por la ciudad y dicta, en principio, un plazo de ocho meses para su consumo antes de que sean comisadas ${ }^{39}$. No obstante, rollos de tela de China continúan moviéndose por sus circuitos de comercialización y el oidor de Quito, Diego de Armenteros, emprende la práctica de inspección y el consecuente embargo de la que se encuentra en stock por las tiendas de la ciudad ${ }^{40}$.

Sin duda, el mercado principal para la ropa de China en Sudamérica es la ciudad de Lima. Una expresión de la magnitud que alcanza este comercio nos la ofrece en 1612 el Cabildo de Lima al sostener que, aun en la prohibición, las ventas y reventas que se hacen en la contratación de México y el estanco de la «ropa de la China» constituyen la mitad de la suma total que se recauda de alcabalas en la ciudad ${ }^{41}$. Los más interesados para su venta,

36 Grau y Monfalcón [1637], 1734: 64-78.

${ }^{37}$ En el apartado final sobre el consumo retomo el papel clave de la seda madeja de China o del algodón oriental como insumo para su elaboración en los talleres novohispanos.

38 AGI, Panamá, vol. 16, reg. 2, núm. 23: 11.

${ }^{39}$ El presidente de la Audiencia de Quito sobre diversos asuntos, 1608, AGI, Quito, vol. 9, reg. 11, núm. 80: 6 .

${ }_{40}$ En muchas de ellas se encuentran tafetanes, rasos, sedas y cordobanes de China. Expediente de ropa de china en Quito, AGI, Quito, vol. 9, reg. 11, exp. 82: 13-15.

${ }^{41}$ Concejo Provincial de Lima, 1950, vol. 17: 171-172. 
almacenamiento y posterior redistribución son los grandes mercaderes limeños. En ese mismo año, el virrey del Perú, marqués de Montesclaros, le escribe a Felipe III que los introductores de la ropa de China son «vecinos de gruesos caudales», a quienes «no se les ha tomado un hilo de ropa» ${ }^{42}$. Ellos llegan a tener el control del puerto de El Callao; el surgidero más visitado por sus embarcaciones procedentes de Acapulco. En 1605, el obispo Loyola, señala:

...muchos millones de pesos que van a las Filipinas y esto que digo no es cosa sabida por relación, sino como testigo de vista, que vi una vez en el Callao una nao con mercaderías de la China que valía más que cuanto ha entrado por este puerto de Buenos Aires en cincuenta años y más que vale toda esta provincia. Y como ven que con estos abusos tan grandes quiebra el comercio de España a las Indias echan la culpa a este puerto de Buenos Aires, siendo ello muy al revés ${ }^{43}$.

Un breve análisis de aquella frase de «los muchos millones de pesos que van hacia Filipinas» ${ }^{44}$. La llegada de «ropa de la China» al Perú se traduce en notables salidas de monedas de plata hacia China. Según los informes de virreyes, obispos y comerciantes, entre 1580 y 1620, la movilización de plata en barra o en moneda desde el Perú hacia la Nueva España se estimaría entre los 2 o 3 millones de pesos anuales ${ }^{45}$. El propio obispo Loyola afirmará en el año 1607 que se «llevan cada año 2 millones de plata que va a pasar a la China ${ }^{46}$. Una porción de ese flujo de metálico peruano que viaja hacia Acapulco, en particular la moneda de plata, se embarca en el galeón de Manila junto con la moneda mexicana. Hacia 1602, el cabildo de México le informa a la Corona que la exportación de plata alcanza los 5 millones de pesos ${ }^{47}$; cifra que se mantendría en la década siguiente ${ }^{48}$. Es muy posible que sean referencias mínimas si tomamos en cuenta los 12 millones de pesos en plata

${ }^{42}$ Sobre la contratación de Nueva España al Perú, 1612, AGI, Lima, vol. 36: 126.

43 Molina, 1953: 63. Loyola, 1989: 79-80.

${ }^{44}$ Es bien sabido del boom de la producción de plata de Potosí a partir de 1570. La innovadora técnica de amalgama combinando plata y azogue de Huancavelica permite que el cerro llegue a producir más de la mitad del metal en circulación por Hispanoamérica y por las rutas mundiales de comercio. Bekewell, 1989: 242. Jara, 1966: 93-118. Entre 1600 y 1620 la producción detiene su crecimiento y a partir de esta última fecha iniciará un descenso que recién se podrá revertir en las primeras décadas del siglo XVIII. Las cifras pueden verse en: Bakewell, 1989: 97-113.

45 Ramos, 1970: 233. Suárez, 1995: 34. Flores, 2005: 387.

${ }^{46}$ Carta de Martín Ignacio de Loyola al presidente del Consejo de Indias, AGI, Filipinas, vol. 35 , núm. $47: 823 \mathrm{v}$.

47 Flores, 2005: 387.

48 Hoberman, 1991: 216. Valle Pavón, 2005: 231. 
novohispana y peruana que salen desde Acapulco hacia Filipinas en $1597^{49}$. Por otro lado, la denuncia del obispo de Buenos Aires es una defensa a la apertura del comercio por el puerto de Buenos Aires. Al evaluar las razones de por qué los galeones de tierra firme se encuentran en crisis, Loyola descarta por «insignificante» el contrabando realizado por los portugueses por la costa austral y dirige todas sus críticas hacia los comerciantes de Lima y sus conexiones con México en torno a la contratación de la China.

Las apreciaciones del virrey Montesclaros y del obispo porteño Loyola nos acercan a otra de las razones que ubican a Lima como punto privilegiado en la importación de «ropa de la China»: la contaminatione, la corrupción. Religiosos, funcionarios aduaneros y de la Armada del Sur, jueces privativos, oidores y, por supuesto, mercaderes tejían una red de connivencia para el ingreso de los bienes. El problema nace, según Loyola, en la raíz del circuito transpacífico, cuando los propios capitanes de los galeones, en clara complicidad con los mercaderes de la ciudad de México, mueven mercaderías y plata sin registrar. El obispo sugiere la creación de un consulado de Manila; una corporación que vendría a contrarrestar el poder novohispano y ordenar la distribución de la carga ${ }^{50}$. Por su parte, Montesclaros nos ofrece un breve, pero contundente, relato sobre cómo funciona la red de corrupción entre México y Perú por el mar del Sur. Decía que «las religiones son los primeros que esconden los fardos en sus conventos y chacras»; los comerciantes y funcionarios «echan la capa a este delito», mientras que los jueces privativos «ajustan moderadamente su obligación»; y cuando «pasa a probanza la pieza de seda y cualquier otro género que conocidamente es de China tiene todos los testigos que a menester para darla de México» ${ }^{51}$. Todos, finaliza el virrey, «salen libres del riesgo o el castigo es tan moderado que no es comparable con la ganancia del trato» ${ }^{52}$. En resumidas cuentas, aun afrontando una multa, los comerciantes de Lima obtenían ganancias en el trato con la Nueva España.

Ahora bien, las telas y tejidos del Oriente importadas a Lima no sólo son para su plaza consumidora. Así como México importa más de lo que necesita, Lima cuenta con un excedente que almacena en la ciudad para su redistribución

49 Borah, 1975: 227-236.

50 «El remedio propio de este negocio consiste en que se haga un consulado en Manila y que allí se proveen los capitanes y oficiales y allí se señale a cada vecino de las Islas las toneladas de ropa que han de embarcar, con esto se pondría remedio total a este mal y los de las Islas por su bien propio y por sus intereses procurarán tratar ellos solos», Carta de Martín Ignacio de Loyola al presidente del Consejo de Indias, AGI, Filipinas, vol. 35, núm. 47: 823v.

51 Ibidem: 126-127. Toda tela o tejido de la China se podía enmascarar con los términos «labrada en México», «de la tierra» o «de ser de Castilla». Álvarez, 2013: 76.

${ }^{52}$ Sobre la contratación de Nueva España al Perú, 1612, AGI, Lima, vol. 36, s/n de exp.: 127. 
hacia los mercados de Chile, Charcas, la Gobernación de Tucumán y el propio complejo rioplatense. Relato un caso representativo al respecto. En abril de 1608, el virrey Montesclaros se encuentra en El Callao, gestionando «apretadas diligencias añadiendo a las ordinarias acerca de la prohibición de mercaderías que venían de Nueva España» ${ }^{53}$. Su presencia trae resultados, pues «queda cantidad de ropa condenada que me dicen puede valer cuarenta mil pesos a los precios de aquí, siendo estas ropas de la China» ${ }^{54}$. Lamentablemente, el documento no ofrece un detalle del textil comisado, pero sí nos informa que una porción es tafetán, una suerte de seda ordinaria para el consumo cotidiano de diferentes grupos sociales. A contrapelo de lo que ordena la legislación, Montesclaros decide por su entrada, elaboración y consumo.

...fue preciso gastar cantidad de tafetán de la China en forros de sombreros que se enviaron a Chile [...] había una partida de mil seiscientos sombreros y para aforrarlos fueron menester doscientos y treinta y una piezas de tafetán, de diez y once varas, que montaron tres mil pesos de a ocho reales ${ }^{55}$.

Las piezas de tafetán chino constituyen un artículo necesario para los obrajes de Lima que realizan sombreros. Montesclaros justifica su decisión al «no hallarse otro textil en la ciudad». Esta mención supone una escasez de textil europeo o castellano en circulación; fenómeno que no debe resultar raro dado que galeón español, tiene grandes problemas para despachar sus textiles en Portobelo.

Chile no es el único rincón austral que cuenta con «ropa de la China» procedente de Lima: ellas también circulan hacia las plazas de la Gobernación de Tucumán y el puerto de Buenos Aires. En 1605, el obispo de Buenos Aires, Loyola, le escribe una carta a Felipe III que contiene las siguientes líneas:

...ha entrado tanta ropa de la China en el Perú de contrabando y contra toda razón que no hay provincia por acá de Buenos Aires y Tucumán que no esté llena de ella, y tan buena y barata que las cosas de España ya no valen nada, lo cual es en grandísimo daño de los derechos reales pertenecientes a su majestad en España $\mathrm{y}$ en los puertos donde las flotas se despachan ${ }^{56}$.

${ }^{33}$ Carta del virrey Montesclaros a Felipe III desde el puerto del Callao, 1608, AGI, Lima, vol. $35, \mathrm{~s} / \mathrm{n}$ de exp.: 43.

${ }^{54}$ Idem.

55 Expedientes cartas de Virreyes Perú, 1604-1610, AGI, Lima, vol. 35, s/n de exp.: 43v.

${ }^{56}$ El obispo del Río de La Plata a su merced. Que se tripliquen los despachos tocantes a la contratación con las Filipinas y las mercaderías y ropa de la China que se prohíben en el Perú, AGI, Charcas, vol. 135: 1. 
Resulta sorprendente que la gravitación del comercio de «ropa de la China» alcance a Buenos Aires. El pobre nivel de intercambio que presentan las ferias de Portobelo no se explica, según Loyola, por el contrabando portugués de Buenos Aires sino por el textil oriental que entra desde El Callao, pues:

...la centésima parte de la ropa de China que este año ha entrado en el Perú, es más que cuanta ha entrado por este puerto en 50 años y estoy admirado de algunos ministros de su majestad que tanto procuran cerrar este puerto siendo una minoría cuanto viene por él y se les da tan poco de esa puerta tan grande [El Callao] donde van cada año tantos millones ${ }^{57}$.

Es evidente la parcialidad de Loyola en su defensa por la apertura comercial de Buenos Aires. Celebra el permiso otorgado en 1604 por la Corona al puerto porteño para «sacar harinas» hacia Brasil y así contrarrestar el comercio portugués que «se hace desde Brasil a Potosí y de Potosí al Brasil $»^{58}$. En alianza con el gobernador de Buenos Aires, Hernandarias de Saavedra, a quien define como «humilde, de altos pensamientos y que actúa con determinación» ${ }^{59}$, intenta convencer al Consejo de Indias que la permisión de sacar frutos frenará el avance de los portugueses hacia el puerto porteño y no perjudicará al comercio de «tierra firme» ${ }^{60}$. La raíz del problema en los intercambios por Portobelo está, según el obispo, por el frente del Pacífico; en el abastecimiento de productos extranjeros que hacen los comerciantes de Lima desde México por el mar del Sur ${ }^{61}$.

57 Idem.

${ }_{58}$ Carta de Martín Ignacio de Loyola al presidente del Consejo de Indias, AGI, Filipinas, vol. 35, núm. 47: 824.

59 AGI, Charcas, vol. 135, s/n de fols.

${ }^{60}$ Loyola inscribe toda problemática económica de Buenos Aires en el marco imperial. La presencia de los portugueses por Buenos Aires resulta mínima si se compara «con los que han entrado sin licencia por México y Perú que están llenos de ellos». De hecho, los comerciantes portugueses ubicados en estos dos puntos, según el parecer de Loyola, son los responsables de la contratación de China por el mar del Sur. Molina, 1953: 62-63. Parte de la carta también es reproducida en la introducción realizada por Tellechea a la obra Viaje alrededor del Mundo, Loyola, 1989: 79.

${ }^{61}$ La crisis que se produce en el comercio oficial por Portobelo de principios del siglo XVI presenta razones más complejas que el simple fenómeno del contrabando. No se puede omitir que su decaimiento comienza antes de la consolidación del contrabando extranjero. La parálisis de los intercambios en la feria oficial proviene desde la lógica del propio sistema monopólico; una crisis operada por sectores mercantiles y autoridades políticas de las Indias que debían, en teoría, proteger la exclusividad del sistema. Con sus prácticas y redes, estos agentes tuvieron la capacidad para crear un verdadero esquema mercantil alternativo combinando ejes de comercio oficiales e ilícitos como los que en esta oportunidad expongo en el 


\section{LA LUCHA CORPORATIVA POR EL COMERCIO DE LA ROPA DE CHINA}

La corriente continental de ropa china (más otros géneros europeos y castellanos) que se movilizan desde México hasta los mercados más australes del virreinato andino es una de las máximas preocupaciones de la Universidad de los mercaderes de Sevilla. Las protestas de los comerciantes sevillanos sobre el comercio transpacífico se multiplican hacia las últimas décadas del siglo $\mathrm{XVI}^{62}$. La baratura de las sedas chinas y las elevadas salidas de moneda de plata hacia China son fenómenos que amenazan el buen desenvolvimiento del comercio español trasatlántico. Aquí quisiera rescatar uno de los tantos informes enviados por aquella corporación mercantil al Consejo de Indias en donde se expresa con sumo detalle su posición sobre la extensión del circuito asiático hacia el Perú. Ante el fracaso de la política económica prohibitiva del mar del Sur, en 1610, la corporación mercantil española solicita cortar de raíz el problema anulando la contratación entre Manila y Acapulco. En su reemplazo, le propone al Consejo de Indias que el comercio asiático corra por el contacto directo entre España y Filipinas a través del cabo africano de Buena Esperanza. El nuevo lazo con China ubicaría a España como la principal abastecedora del tejido oriental en los mercados hispanoamericanos, quitando la facultad que hasta entonces detentan los comerciantes la ciudad de México y de Lima ${ }^{63}$. Por un lado, es una medida de transformación geopolítica, que busca desplazar a México de aquella centralidad adquirida en el comercio asiático porque al anular el galeón de Manila se clausuraría la circulación de la ropa de China por el Perú. En segundo lugar, es un intento por reimpulsar el comercio de flotas de Portobelo y no hay mejor manera para España que cerrar los contactos intercoloniales por el mar del Sur clausurando así la movilización de los bienes europeos y castellanos hacia el Perú que llegan previamente a Veracruz a través de las flotas españolas del Atlántico. Es que hay un pleno consenso entre los defensores de las flotas de Portobelo sobre la idea que la movilización de la ropa de China se inscribe en un problema mayor, resultado del reenvío hacia el Perú de los excedentes de telas extranjeras que se encuentran en la Nueva España. En 1607, la Audiencia de Panamá dice que la «contratación de la China» no es

ensayo. Sigue vigente el texto de Moutoukias para conocer el contrabando por Buenos Aires en el siglo XVII. Moutoukias, 1988.

${ }^{62} \mathrm{La}$ primera protesta formal sevillana al flujo filipino sería de 1587; le siguen otras de 1591 y 1593. Véase: Flynn y Giráldez, 1996: 59.

${ }_{63}$ Real Cédula al marqués de Salinas, virrey de Nueva España, 1610, AGI, Filipinas, vol. 329, leg. 2: 118-120. 
la que provoca «la disminución de las flotas de Portobelo» sino que habría que atender con mayor preocupación «las mercaderías que vienen de España para el Perú que toman su derrotero por la Nueva España» ${ }^{64}$. Este último aspecto resulta importante para los intereses de la corporación sevillana y del propio poder político peninsular pues, al no tener México «la puerta abierta de Acapulco», los mercaderes de Lima volverían a encauzar su trato por el alicaído camino de Portobelo. El informe de la Audiencia de Panamá continúa argumentando que «sus vecinos tuvieron a los principios grandes aprovechamientos y ganancias por la frecuencia de las flotas» ya que todos los años venían a Portobelo un «número de más de cuarenta navíos con cargazón de todos géneros». Pero desde hace unos años «las flotas comenzaron a tardar dos años y a veces tres y venir menores en número de navíos e importancia de cargazón» ${ }^{65}$. Como un fiel reflejo de la crisis del comercio de «tierra firme», no debe resultar raro que también se desplome el número de los factores peruanos embarcados en los galeones rumbo al mercado hispalense ${ }^{66}$. A pesar de la lejanía geográfica y de una aparente disociación, la propuesta sevillana es un análisis sumamente fino de las conexiones e interacciones de los flujos comerciales por el imperio. En resumidas cuentas, la eliminación del galeón de Manila con el consecuente cierre a la extensión del comercio por el mar del Sur contribuiría a «atlantizar» el comercio asiático en manos de los peninsulares y a reimpulsar el tráfico directo entre España y el Perú a través de los galeones de «tierra firme».

La respuesta de los comerciantes de Lima al proyecto sevillano no se hace esperar ${ }^{67}$. No sólo llegan a desacreditar cada uno de los argumentos apuntados por la corporación peninsular sobre la supuesta contracción que genera la contratación de China en el comercio trasatlántico de galeones sino que van más lejos: solicitan la reapertura del comercio con el Oriente. En las primeras líneas de su informe dicen que:

...el haber enflaquecido este comercio de las Indias a España no son la causa las mercaderías que de la China entran en aquel reino del Perú; sin el mal orden

${ }^{64}$ Descripción de Panamá y su provincia; sacada de la relación que por mandado del Consejo hizo y envió aquella Audiencia, 1607, reproducido en Colección de Libros y documentos..., 1908: 174.

65 Ibidem: 175-176.

${ }^{66}$ Los factores peruanos se dirigen a Península para el trato, evitando la mediación de los galeonistas peninsulares. García Fuentes, 1997: 114.

${ }^{67}$ Informe sobre una propuesta de los mercaderes de la ciudad de los Reyes de Perú acerca del comercio con China, ¿1610?, AGI, Filipinas, vol. 35, exp. 47: 825-826. 
de las armadas y flotas y las invernadas que son la total perdición y destrucción de los mercaderes ${ }^{68}$.

Desmienten que la causa de la decadencia del comercio de Portobelo sea la entrada de las telas y tejidos de China que llegan desde Acapulco. Según la posición peruana, el problema se encuentra en el propio funcionamiento de las flotas, «su mal orden». Por una propia decisión peninsular las escuadras arriban sin contemplar las reales necesidades de los mercados del Perú. Las invernadas -internaciones peninsulares por largos período en el virreinato con el propósito vender sus mercancías directamente con el consumidor- son también prácticas cuestionadas desde Lima porque terminan excluyendo del proceso de intercambio al gran mercader limeño.

En segundo lugar, los elevados costos impositivos y el prolongado tiempo que requiere la obtención de rentabilidades por el canal del galeón trasatlántico son razones para que el comerciante peruano prefiera una inversión por la vía del mar del Sur. En el informe se subraya que al canalizar sus capitales por la vía oficial de Portobelo deben esperar al menos cuatro años en evaluar si hubo o no rentabilidad, mientras que «el viaje a la Nueva España lo hacen en un año y así pueden hacer muchos empleos con su dinero» ${ }^{69}$. Vale señalar un dato relevante: la corporación andina reconoce su inclinación hacia el trato con Acapulco pero la concede principalmente como una vía de almacenamiento de géneros europeos y castellanos, minimizando la «contratación de la China» ${ }^{70}$.

Ahora bien, el argumento peruano trasciende el plano de la comercialización para atender la problemática del consumo. El aumento del número de españoles por el Perú en los últimos veinte años representa un amplio grupo dispuesto a consumir las ropas que vienen de Europa. De hecho, resulta muy necesario su abasto porque los españoles:

\footnotetext{
${ }^{68}$ Ibidem: 825.

${ }^{69}$ «los derechos son excesivos porque al entrar el dinero en España pagan a 7,5\% para los galeones y al tiempo que salen las mercaderías de Sevilla pagan a 3,5\% y lo más principal que causa este daño es el tiempo porque con las invernadas desde el día que el dinero sale del Callao hasta que en mercaderías vuelve por lo menos se pasan tres años y primero que lo embolsan pasa otro año y a un año y medio porque no se puede vender todo de contado por manera a que este dinero que pudiera hacer dos ganancias como solían en cuatro años no hace más que una y por mucha que sea la ganancia no puede ajustar a los dos particularmente echándoles los derechos», Ibidem: 826.

${ }^{70}$ Recordemos la frase citada en páginas anteriores donde se dice que «aunque se traen mercaderías de la China la mayor parte de la ropa que compran [en México] es de la España», Ibidem: 825.
} 
...se tratan muy costosamente, todos se visten de sedas y de los más precioso y costoso. Las galas y vestidos de las mujeres son tantas y tan excesivos que en ningún reino del mundo no lo son tanto, de manera que si cada año entrasen cuatro flotas en el Perú se venderían toda la ropa y todo lo demás que se llevase ${ }^{71}$.

El galeón de «tierra firme», que en sus mejores épocas llegaba con puntualidad bianual y ahora cada cuatro años y de manera espaciada, es la causa para que españoles que viven en el Perú «se aprovechen de las ropas que vienen de Nueva España y de la China». Aquí el informe de Lima toca una declaración crucial -quizás la más resonante de todas- sobre la razón por la cual la «contratación de la China» no ejerce ningún efecto negativo en el intercambio español de Portobelo. Es que la ropa que viene de China no estaría destinada al público que consume ropa europea; sino a otros grupos sociales de menores recursos:

Estas ropa de la china no se visten sino los muy pobres y negros y negras y mulatas y mulatos, muchos indios y mestizas y en gran multitud de gente que también gastan las sedas de la China los templos de los indios con que están adornados $[\ldots]$ que antes por no poder tener sedas de España no lo estaban adornados ${ }^{72}$.

Si esto fuera cierto, la trato oriental por el Pacífico y el comercio trasatlántico apoyado en el régimen monopólico español responden a dos culturas consumidoras diferentes. Más que una competencia estarían complementándose. De hecho, el anónimo funcionario español que revisa el informe acuerda con la posición limeña sugiriendo la apertura del comercio asiático

...siendo cierto cuan bien le está al Perú para los pobres y para la gente menuda del que en gran número y para el ornato de los templos de los Indios haya ropa de la $\mathrm{China}^{73}$.

Le dedicaré un apartado especial a la cuestión del consumo más adelante. Por ahora, valdría señalar que el informe de Lima termina por proponer que se les «abra el comercio directo con la China», con el permiso de enviar un millón o medio millón de plata con un retorno de telas chinas por valor de seis millones, pagando el $10 \%$ en concepto de derechos reales. Si esto no se concede, ofrece una segunda vía: el permiso de ingresarlas desde la Nueva

\footnotetext{
71 Ibidem: $825 \mathrm{v}$.

72 Ibidem: 826.

${ }^{73}$ Idem.
} 
España, pagando el siete por ciento de ella; adicionando un 2\% de impuesto en la aduana de El Callao a los 5\% que se pagan en la Nueva España.

Por su parte, una similar sugerencia a la del comercio limeño es la que brinda en 1612 el virrey del Perú, marqués de Montesclaros ${ }^{74}$. Define como «intratable y de poca sustancia» el cierre del tráfico entre la Nueva España y el Perú, porque «a Guatemala se vendría a introducir comercio de ambas provincias con los mismos inconvenientes y aún mayores» ${ }^{75}$. Al cerrar el tráfico no habría ningún navío «para solo bajar a Tierra Firme el año de flota» y no se podrían conservar las provincias de Guatemala y Nicaragua; espacios que, al prohibirse el ingreso de plata peruana por Acapulco, estos espacios reciben el metálico para alcanzar por vía terrestre los textiles de China que están en México ${ }^{76}$. Montesclaros insiste con la posición de reapertura que ya venía sosteniendo como virrey novohispano ${ }^{77}$. Al menos, se debería permitir un navío que viaje desde El Callao a Acapulco con monedas de plata y que a su regreso:

...pudiese traer ropa de Castilla y de China cargando mucho los derechos de la salida de Acapulco y de la entrada del Callao, donde se abriesen todos los fardos y cajones conviniéndolos con las partidas del registro y libro de sobordo cobrando con rigor los derechos y no dispensando en una vara que haya en cada pieza más de las que vienen registradas. Con lo que se hará menor la granjería y menos codiciable y apetecerán y tendrán por mejor la correspondencia de Tierra Firme ${ }^{78}$.

Montesclaros es consciente de los efectos que produce el movimiento del Pacífico sobre el régimen monopólico de comercio trasatlántico. La legalización y su consecuente peso impositivo entre México y Perú disminuirán el interés limeño por la ruta y renovarían el movimiento de sus capitales en la contratación de tierra firme. Montesclaros sabe que la principal preocupación de la Corona es que México provoque la pérdida de la «relación de dependencia» sobre el Perú; un punto fundamental de la controversia establecida con la corporación mercantil sevillana. Por ello, intenta convencer a la Corona que si:

${ }^{74}$ Carta en respuesta al informe sobre mudar a España la contratación de México a Filipinas, 12 abril 1612, Biblioteca Nacional, Madrid (BNM), Papeles referentes al gobierno del Marqués de Montesclaros, Virrey del Perú, y otros documentos sobre el estado de Filipinas y su comercio con México: 71-81.

75 Sobre la contratación de Nueva España al Perú, 16 de septiembre de 1612, AGI, Lima, vol. 36: 127.

${ }^{76}$ Idem.

77 Latasa Vasallo, 2002: 877-897.

78 Sobre la contratación de Nueva España al Perú, 16 de septiembre de 1612, AGI, Lima, vol. 36: $127 \mathrm{v}$. 
...la principal cargazón de España a México es vino, aceite y algo de lencería [...] por lo que toca al vino México es incapaz de consumir más vino y aceite del que al presente gasta y ya queda conseguida la forzosa dependencia. Que lo que toca a lienzo lo podría suplir en parte sirviéndose del que los indios hacen de algodón y de las sedas que provee Manila para beneficiar y labrar admirablemente en la Mixteca ${ }^{79}$.

La reflexión del virrey amerita varias observaciones. En primer término, minimiza el peso de los textiles europeos que se envían hacia México en las flotas trasatlánticas de Veracruz, cuando sabemos que era uno de los ramos principales de la carga. Al mismo tiempo, otorga un énfasis particular a la comercialización del vino y el aceite español que se destina al mercado novohispano. Con gran cuota de parcialidad llega a decir que «la Nueva España es incapaz de consumir más vino y aceite del que al presente gasta». Aquí intenta ocultar lo que es un hecho de público conocimiento para la época y por los estudios; la existencia de un excedente en la producción vitivinícola en el Perú para su exportación hacia México, Panamá y Guatemala ${ }^{80}$. En 1607, la Audiencia de Panamá le informa al Consejo de Indias que para pagar la «ropa de la China» venida desde México, no sólo se exporta plata sino que «el Perú tiene vino de cosecha para sí y para cargar a Nueva España» ${ }^{81}$. El vino peruano se convierte, junto con la moneda de plata, en un importante medio de cambio para la adquisición de las telas y tejidos de China por el puerto de Acapulco.

Con respecto a Filipinas, Montesclaros recuerda lo necesarias que son las sedas de China como insumo de los obrajes novohispanos, algo que en líneas posteriores analizo con más detenimiento. Se diferencia aquí de la política peninsular que evita cualquier intento de desarrollo de la manufactura colonial. Evidentemente, quiere llegar al fondo del problema e instala en el debate un fenómeno que la Universidad de mercaderes de Sevilla esconde: la dependencia española con respecto a los tejidos de «Francia y Flandes a

${ }^{79}$ Carta en respuesta al informe sobre mudar a España la contratación de México a Filipinas, 12 abril 1612, BNM, Papeles referentes al gobierno del Marqués de Montesclaros, Virrey del Perú, y otros documentos sobre el estado de Filipinas y su comercio con México: 74.

80 Ramos, 1970: 236.

81 En menores proporciones también se moviliza jabón de Guayaquil y de Nicaragua, brea de esta última región y paños de Quito; en Descripción de Panamá y su provincia..., 1607, reproducido en Colección de Libros y documentos..., 1908: 175. Por lo que se sabe el cacao será un artículo de exportación importante a partir de 1610, adquiriendo un papel dominante hacia finales del siglo XVII. Hoberman, 1991: 119-125. Bonialian, 2012: 259-308. 
quien España da siempre en trueque de esto sus tesoros ${ }^{82}$. Para finalizar su informe, Montesclaros desacredita el derrotero propuesto por los comerciantes sevillanos de un comercio con el Oriente a través del Cabo de Buena Esperanza $^{83}$. La ruta sugerida es, para el virrey, desconocer el control efectivo que tienen los portugueses por el paso africano en su vinculación mercantil con la India y China. También resulta inviable el camino por el Cabo de Hornos; derrotero que por entonces es visitado por corsarios europeos y por periódicas naves mercantes holandesas ${ }^{84}$.

\section{LA «ROPA DE LA CHINA» Y SU CULTURA CONSUMIDORA}

En una carta que envía al Consejo de Indias en el año 1602, el virrey de la Nueva España, conde de Monterrey, ensaya un análisis muy original sobre la problemática del comercio asiático. En ella coloca al consumo como punto de partida para comprender el «exceso» en los ingresos de «ropa de la China» y las salidas de plata hacia Filipinas, llegando a «sentirse en esta plaza gran falta de moneda». No está de más, dice el virrey, que la ropa que se trae del Oriente, que «es cosa de volumen», se encierre y se examine en los almacenes de la Nueva España; pero lo más importante sería atender:

...en el uso de este género de ropa en la Nueva España; no se pone alguna limitación, en manera que no se impidiese el vestirse de ella a las personas que al virrey le pareciesen necesitadas ${ }^{85}$.

Limitar el consumo en el uso de la ropa de China es, según el virrey, la solución de base que evitaría reducir los niveles de su importación. Lo que no queda claro en la cita es quiénes son las personas «necesitadas». Aquí se abren dos posibilidades: que se reduzca el uso de las telas chinas a los grupos de españoles ricos y privilegiados o, por el contrario, que el consumo de ellas sólo se destine a los sectores sociales que no pueden acceder a los costosos tejidos castellanos o europeos. De todas maneras, las palabras del conde de Monterrey dejan entrever que la «ropa de la China» llega a un amplio y diver-

82 Carta en respuesta al informe sobre mudar a España la contratación de México a Filipinas, 12 abril 1612, BNM, Papeles referentes al gobierno del Marqués de Montesclaros, Virrey del Perú, y otros documentos sobre el estado de Filipinas y su comercio con México: $74 \mathrm{v}$.

83 Ibidem: 80.

${ }^{84}$ Crespo Solana, 2013: 479-507.

${ }^{85}$ Carta del conde de Monterrey, virrey de la Nueva España, 15 de mayo de 1602, AGI, Filipinas, vol. 35, exp. 47: 820. 
so mercado consumidor, desde los estratos sociales superiores hasta sectores sociales de menores recursos.

Una de las características que se les atribuyen en los documentos a las sedas chinas es su baratura. Al menos desde 1580 la consumen los campesinos indígenas de las islas Filipinas. Estamos en presencia de lo que el historiador Alonso Álvarez identificó como uno de los elementos que alientan un cambio estructural de la economía filipina: al disponer de plata americana dada la contraprestación de los servicios a españoles, los indígenas de Filipinas adquieren tejidos chinos baratos y abandonan las bases del cultivo de algodón y la confección de prendas en los obrajes textiles domésticos ${ }^{86}$. Si este textil barato llega al archipiélago oriental para el consumo indígena no nos debería resultar extraño que también alcance a un amplio mundo consumidor hispanoamericano.

No deberíamos olvidar que la gran mayoría de las importaciones que se realizan con el galeón de Manila por estas décadas consisten en seda bruta y, en menor porción, algodón, dispuesto para su elaboración. Horacio de Levanto (1594), un genovés que reside en la Nueva España en los primeros años del siglo XVI, deja un interesante testimonio sobre el caso. Fundador de la Casa de la Moneda de la ciudad de México e importante agente mediador de las negociaciones entre el poderoso consulado novohispano y el Consejo de Indias $^{87}$, conoce como pocos la tipología de bienes que ingresan por Acapulco y su cultura consumidora. En su Memorial publicado en 1617 dice que:

...los tejidos de seda se consumen en la Nueva España mucha cantidad, que los gastan toda calidad de personas, así ricos como pobres en unas u otras cosas [...] de la seda madeja, pelo y trama se labran en la Nueva España terciopelo, terciopelado, mantos, tocas, pasamanos, y muchos tafetanes llanos, de los cuales se llevan al Perú y otras partes de las Indias. Y hallan que la seda madeja de China es más pareja y limpia y apropiada para los dichos tafetanes y otras obras que la que llaman mixteca que se cría en la Nueva España en poca cantidad menos de la que es menester para el trato que hay de seda en el reino, en el cual se sustentan de él muchas personas en la ciudad de México, de la Puebla y Antequera ${ }^{88}$.

Con la cuota de parcialidad que Levanto nos puede informar, hay argumentos que no resisten discusión. Lo que más ingresa por Acapulco es la seda

${ }^{86}$ Álvarez, 2013: 63-65.

87 Díaz Blanco, 2014: 55.

${ }_{88}$ Memorial sobre el trato de la China con la Nueva España y estos Reinos dirigido al Señor don Fernando Carillo, de Horacio Levanto (1617), Biblioteca Nacional de España, Biblioteca Digital Hispánica, R/17270 (6): 2. 
bruta, lista para ser confeccionada en los talleres novohispanos y responder al vestuario de tantos «ricos como a pobres». Mucho de los tejidos que se llevan para el Perú categorizados como «efectos locales» están compuestos de seda china, lo que facilita su ocultamiento y sus mínimos costos impositivos. En segundo lugar, la seda que se produce en México es insuficiente para el abasto interno, lo que genera mayor necesidad de contar con el insumo del Oriente. Dicho esto, la imagen tradicional dada por la historiografía de unos bienes suntuosos y de elite se desvanece. Lo que ingresa a la Nueva España es, en su mayoría, rudimentario, ordinario y como materia primera, antes de convertirse en un producto final para su consumo. Levanto brinda más información: si la seda del Oriente se destina tanto a ricos como a pobres, el algodón (la sinabafa) con la que se elaboran camisas, calzones y tilmas y cobijas lo usan los indios, indias y trabajadores mineros ${ }^{89}$.

En numerosas fuentes consultadas aparece la referencia «barata» sobre la «ropa de la China». El término podría admitirse con relación al precio de las sedas transportadas a Veracruz y a Portobelo desde España. Pero me pregunto si el concepto de baratas se podría extender sobre la práctica de consumo en el vestuario de las clases «populares» de la América española colonial. $\mathrm{Y}$ aquí entramos en un terreno resbaladizo donde las fuentes que dispongo, prácticamente descriptivas, no permiten avanzar en un análisis que relacione el precio, calidad y accesibilidad del textil de la tierra con la ropa china. Nadie duda que los primeros, compuestos de algodón y lana que se producen en los obrajes, telares sueltos y chorrillos de la Nueva España y la región andina constituyan la base del vestuario de los consumidores de muy bajo poder adquisitivo. Pero vale recordar que mucho del insumo oriental (como la seda madeja o el algodón de Bengala o de las propias islas Filipinas) termina por «convertirse» en productos locales. No podría ahondar más sobre esta inédita problemática con las fuentes que presento; pero vale considerarla para futuras investigaciones que cuenten con evidencia más sólida y contundente.

La asociación de las telas del Oriente con el adjetivo de baratas es una regla común. Resulta difícil comprender que ellas llegaran a precios tan competitivos a manos de consumidores de bajo poder adquisitivo. Tan sólo pensemos en los costos de comercialización que sufrían estas mercaderías desde Filipinas hasta la misma Lima. Lo cierto es que la baratura de las prendas orientales se explicaría ante todo a su mediana u ordinaria calidad. Ya lo dice hacia 1581 el virrey novohispano, el marqués de Villamanrique, cuando señala que las sedas de China, «fuera de un lustre que tienen», son «todas falseadas». $\mathrm{Su}$ consumo es muy rápido, porque la «gente se va a lo barato y todo cuanto

\footnotetext{
89 Ibidem: 3.
} 
traen se vende ${ }^{90}$. El primer comentario del virrey acerca de la falsedad de las sedas apuntaría a la copia oriental que se hace de los tejidos europeos; una imitación que emprenden los sectores sociales de menores recursos sobre las prácticas del vestir de los grupos opulentos.

El consumo de la tela china se extiende, como una suerte de moda, desde las esferas de elite hacia las clases sociales inferiores ${ }^{91}$. El fenómeno parece adecuarse a la trickle down teory; aquel mecanismo visto por historiadores económicos donde la difusión «gota a gota» de las modas de vestuario se desparraman desde arriba hacia en la pirámide social. Ahora bien, este fenómeno cultural que se da en torno a la copia o imitación no debería opacar los atributos particulares de la «ropa de la China» para amplio y diverso consumo. Es que ella, en sus diferentes versiones, satisface la demanda de distintos grupos sociales, no sólo de la Nueva España sino también del Perú y tierra firme. En 1591, desde Panamá, los oficiales reales denuncian que desde Acapulco:

...se traen especial cosas de seda a muy baratos precios, que se visten y remedian con ellos gente pobre porque es más barato con lo de Castilla pero no tan buena ni con mucho ${ }^{92}$.

Se podría afinar un poco más sobre el destino consumidor de las sedas chinas. Las autoridades de Panamá no tienen dudas de que es «gente pobre» la que se viste con telas del Oriente. También lo sostendrá el Cabildo de Lima en 1595, afirmando que desde su prohibición, el Perú carece de seda y de vestimenta para «los pobres». En sus actas el Cabildo anota que:

...el procurador general de esta ciudad propuso del gran inconveniente que había en que no viniese a este reino ropa de la China y que a esta causa se habían encarecido e iban encareciendo cada día más las mercaderías especialmente sedas, cera y otros géneros y que convenía acudir al remedio de esto pues el venir mercaderías de la China a este reino y de este reino ir por ellas no era ningún inconveniente, antes era en pro y utilidad de él y de los pobres por valer como valdrán y han valido las dichas mercaderías a mejores precios que después de la prohibición ${ }^{93}$.

Contundente afirmación la del Cabildo de Lima; una premisa que aparece en otros documentos. Instalado en la ciudad de Lima hacia 1620 León de Portocarrero, comerciante judío portugués, observa un suceso idéntico, en el que

90 Álvarez, 2013: 48.

91 Veblen, 2004. Simmel, 2008.

${ }_{92}$ Carta de Miguel Ruiz de Elduayen, contador de hacienda de Tierra Firme, al Presidente del Consejo de Indias, Pedro Moya de Contreras, 1591, AGI, Panamá, vol. 33, núm. 146: 3.

${ }_{93}$ Concejo Provincial de Lima, 1943, vol. 12: 362. 
con la seda china «se visten de ellas los pobres porque son sedas baratas» ${ }^{94}$. La mención del precio barato de lo oriental está en relación directa con el alto valor de los textiles europeos y castellanos. En 1594, el virrey del Perú, Hurtado de Mendoza, llega a brindar una comparación sobre los costos de la vestimenta de diferente procedencia:

...un hombre puede vestir a su mujer con sedas chinas por doscientos reales [25 pesos] mientras que no podría proporcionarle vestidos con seda española por doscientos $\operatorname{pesos}^{95}$.

La alta perfección y el precio elevado de los textiles europeos hacen que su consumo esté reservado a los grupos privilegiados. El resto de la población del virreinato del Perú dispone de los tejidos orientales y los que se producen localmente. Estaríamos en presencia de diferentes vías de demanda: las castellanas para un arco social privilegiado y reducido, mientras que las orientales y las locales para grupos sociales de ingresos medios y bajos (españoles pobres, mestizos, indígenas y hasta esclavos).

Por todo lo dicho, veo la necesidad de relativizar aquel argumento retórico utilizado en la época acerca de la competencia que genera el textil oriental sobre sus pares europeos. En una perspectiva de historia del consumo, el principio de complementariedad entre el comercio trasatlántico y el Pacífico primaría sobre la idea de competencia. Sería un error omitir del análisis la movilización de tejidos europeos y castellanos que se genera entre la Nueva España y el Perú por el mar del Sur, ya que es sobre este preciso comercio en donde recae la mayor responsabilidad de la crisis existente por la feria de Portobelo.

\section{CONCLUSIONES}

Me permito incorporar unas breves reflexiones finales a este ya extenso ensayo. El estudio de la circulación y el consumo de la «ropa de la China» por casi todos los espacios hispanoamericanos es una muestra por demás elocuente de la notable articulación económica entre los continentes. La economía asiática ya no puede verse como un espacio marginal y ajeno en el proceso de

${ }^{94}$ Memoria de todos los géneros de mercaderías que son necesarias para el Perú y sin ellas no pueden pasar porque no se fabrican en la tierra. Biblioteca Nacional de Francia, París (BNF), Manuscritos, Espagnol, vol. 280, núm. 5057: 211-212. En las páginas 235-267 aparecen diferentes tipos de sedas y telas de China que el Perú importa por esas épocas.

${ }^{95}$ Borah, 1975: 122. 
formación y constitución de la economía colonial. Esto lo ponen de manifiesto los informes ofrecidos por virreyes, funcionarios y comerciantes de la época. Afortunadamente, la visión pacífica-asiática comienza a revalorizarse cada vez más en los estudios históricos; algunos de ellos citados en este ensayo. Claro está, que la perspectiva europea-trasatlántica contiene un protagonismo innegable en la historia hispanoamericana. Estoy lejos de plantear algún determinismo entre el Pacífico y el Atlántico. Más bien, resultarían ejes que actúan de forma dialéctica. Proponemos más bien un estudio de sus interconexiones, sus interdependencias, sus relaciones simétricas y asimétricas de acuerdo con cada coyuntura particular.

Una expresión representativa se encuentra en la problemática del consumo abordado en este trabajo. He intentado demostrar que las telas y tejidos de China se destinan a un público consumidor de media y baja condición; grupos sociales que no tienen la capacidad económica para acceder a los finos, lujosos y más caros tejidos europeos. De tal manera, si la meta es articular, desde una visión global-imperial, los fenómenos mercantiles que ocurren entre China, Hispanoamérica y Europa aquí sugerimos el principio de complementariedad. La competencia implicaría la existencia de artículos que están en puja por un mismo mercado; fenómeno que, en el caso tratado, parece correcto si apuntamos a las sedas exquisitas y elaboradas, pero premisa falsa si concentramos la atención en la seda madeja ordinaria y de baja calidad de China, más si pensamos en el algodón comercializado en el galeón oriental como materia prima.

La tensión entre la complementariedad/competitividad también sale a relucir en la lucha corporativa suscitada entre el comercio de Sevilla y el de Lima en torno a la prohibir o potenciar la «contratación de la China» por Sudamérica. Con todo lo sugerente que puedan ser sus argumentos para una u otra posición, todo parece indicar que el principal motivo es quién se beneficiaría de su control monopólico; comercio que, aún con todos los gastos y costes que soporta su circulación como el caso tratado en el ensayo que va desde Filipinas hasta el Perú o para el proyectado desde España hacia América, no dejaría de ser beneficioso y rentable para quien lo emprendiera. 


\section{BIBLIOGRAFÍA}

Alfonso Mola, Marina y Martínez Shaw, Carlos (eds.), El Galeón de Manila, Madrid, Aldeasa, 2000.

Álvarez, Luis Alonso, "E la nave va. Economía, fiscalidad e inflación en las regulaciones de la carrera de la Mar del Sur", Salvador Bernabeú y Carlos Martínez Shaw (eds.), Un océano de seda y plata: el universo económico del Galeón de Manila, Sevilla, Consejo Superior de Investigaciones Científicas, 2013: 25-84. Colección Universos Americanos.

Assadourian, Carlos Sempat, El sistema de la economía colonial: mercado interno, regiones y espacio económico, Lima, Instituto de Estudios Peruanos, 1982.

Bekewell, Peter, Mineros de la montaña roja. El trabajo de los indios en Potosí, 1545-1650, Madrid, Alianza editorial, 1989.

Bernal, Antonio Miguel, "La carrera del Pacífico: Filipinas en el sistema colonial de la carrera de Indias", Leoncio Cabrero (coord.), España y el Pacífico, Legaspi, vol. I, Madrid, Sociedad Estatal de Conmemoraciones Culturales, 2004: 485-525.

Bonialian, Mariano, "México, epicentro semi-informal del comercio hispanoamericano (1680-1740)", América Latina en la Historia Económica, 35 (México, 2011): $5-28$.

Bonialian, Mariano, El Pacífico Hispanoamericano. Política y comercio asiático en el imperio español. La centralidad de lo marginal, México, El Colegio de México, 2012.

Borah, Woodrow, Comercio y navegación entre México y Perú en el siglo XVI, México, Instituto Mexicano de Comercio Exterior, 1975.

Chaunu, Pierre, Seville et Atlantique, 1500-1650, París, Libraire Armand Colin, 1955 1959.

Chaunu, Pierre, Les Philippines et le Pacifique des ibériques (XVI, XVII, XVIII). Introduction methodologique et indices d'activité, París, Sevpen, 1960.

Colección de Libros y Documentos referentes a la Historia de América. Relaciones Históricas y Geográficas de América Central, vol. 8, Madrid, Suárez, 1908.

Concejo Provincial de Lima, Libros de Cabildos de Lima, Lima, Torres Aguirre, vol. 12, 1943 y vol. 17, 1950.

Crespo Solana, Ana, "Las rivalidades hispano-neerlandeses en el Pacífico y la conquista de Australia: de Cornelis de Houtman a Abel Janszoon Tasman (1595-1651)", Anuario de Estudios Americanos, 70/2 (Sevilla, 2013): 479-507.

Díaz Blanco, José Manuel, "Pensamiento arbitrista y estructuras institucionales en la carrera de Indias (siglo XVII): entre la desincentivación y la represión”, Anuario de Estudios Americanos, 71/1 (Sevilla, 2014): 47-77. 
Díaz Trechuelo, María de Lourdes, La Real Compañia de Filipinas, Sevilla, Escuela de Estudios Hispanoamericanos, Consejo Superior de Investigaciones Científicas, 1965.

Flores, Ramiro, "El secreto encanto de Oriente. Comerciantes peruanos en la ruta transpacífica (1590-1610)", Scarlett O'Phelan Godoy y Carmen Salazar Soler (eds.), Passeurs, mediadores culturales y agentes de la primera globalización en el mundo ibérico, siglos XVI-XIX, Lima, Pontificia Universidad Católica del Perú, 2005: 377-409.

Flynn, Dennis y Giráldez, Arturo, "Silk for Silver: Manila-Macao Trade in the Early Modern Period", Philippine Studies, 44 (Manila, 1996): 52-68.

Flynn, Dennis y Giráldez, Arturo (eds.), Metals and Monies in an Emerging Global Economy, Aldershot, Hampshire, 1997.

García Baquero, Antonio, Cádiz y el Atlántico (1717-1778), 2 vols., Sevilla, Escuela Hispanoamericana de Sevilla, 1976.

García Fuentes, Lutgardo, El comercio español con América, 1650-1700, Sevilla, Escuela de Estudios Hispanoamericanos, 1980.

García Fuentes, Lutgardo, Los Peruleros y el comercio de Sevilla con las Indias, 1580-1630, Sevilla, Universidad de Sevilla, 1997.

Grau y Monfalcón, Juan, "Justificación de la conservación y comercio de las islas Filipinas, Madrid, [1637]", Álvarez de Abreu, Extracto Historial del expediente que pende en el Consejo de Indias a instancias de la ciudad de Manila y demás provincias, Madrid, Juan de Ariztia, 1736: 64-78.

Hamilton, Earl, El tesoro americano y la revolución de los precios en España, 15011650, Barcelona, Ariel, 1975.

Hoberman, Louisa, Mexico's Merchant Elite, 1590-1660: Silver, State and Society, Durham, Duke University Press, 1991.

Iwasaki Cauti, Fernando, Extremo Oriente y Perú en el siglo XVI, Madrid, Mapfre, 1992.

Jara, Álvaro, "La curva de producción de metales monetarios en el Perú del siglo XVI", Tres ensayos de economía minera hispanoamericana, Santiago de Chile, Centro de Investigaciones de Historia americana, 1966: 93-118.

Latasa Vasallo, P., "Limitaciones legales al comercio transpacífico: actitud del virrey Montesclaros", Feliciano Barrios (coord.), Derecho y administración pública en las Indias Hispánicas, Cuenca, Ediciones de la Universidad de Castilla-La Mancha, I, 2002: 877-897.

Lejarza, Fidel, “Los archivos españoles”, Misselania Hispánica, IV/10 (Madrid, 1947): 525-585.

Loyola, Martín Ignacio de, Viaje alrededor del mundo, José Ignacio Tellechea (ed.), Madrid, Historia 16, 1989. 
Malamud Rikles, Carlos, Cadiz y Saint Malo, en el comercio colonial peruano (16981725), Cádiz, Diputación de Cádiz, 1986.

Molina, Raúl, "Fray Martín Ignacio de Loyola, cuarto obispo del Paraguay y Río de La Plata (1603-1606)", Missionalia Hispanica, 10/28 (Madrid, 1953): 21-71.

Morineau, Michel, Incroyables gazettes et fabuleux métaux, Londres, Cambridge University Press, 1985.

Moutoukias, Zacarías, Contrabando y control colonial en el siglo XVII: Buenos Aires, el Atlántico y el espacio peruano, Buenos Aires, Centro editor de América Latina, 1988.

Moutoukias, Zacarías, "Una forma de oposición: El contrabando", Máximo Ganci y Ruggiero Romano (coords.), Gobernare il mondo, l'impero spagnolo dal XV al XIX secolo, Palermo, Facoltá di Lettere Palermo, 1991: 333-368.

Navarro García, Luis, "El comercio interamericano por la mar del Sur en la edad moderna", Revista de Historia, 23 (Caracas, 1965): 11-55.

Pérez Herrero, Pedro, “Actitudes del Consulado de México ante las reformas comerciales borbónicas (1718-1765)”, Revista de Indias, XLIII/171 (Madrid, 1983): 77-182.

Ramos, Demetrio, Minería y comercio interprovincial en Hispanoamérica (siglos XVI, XVII y XVIII), Valladolid, Universidad de Valladolid, 1970.

Romano, Ruggiero, Coyunturas opuestas. La crisis del siglo XVII en Europa e Hispanoamérica, México, Fondo de Cultura Económica, 1993.

Romano, Ruggiero, Moneda, seudomonedas y circulación monetaria en las economías de México, México, El Colegio de México, 1998.

Schurz, William Lytle, "Mexico, Peru and the Manila Galleon", Hispanic American Historical Review, 1/4 (Durham, 1918): 389-402.

Schurz, William Lytle, The Manila Galleon, New York, E. P. Dutton \& Co., 1939.

Simmel, George, De la esencia de la cultura, Buenos Aires, Prometeo, 2008.

Suárez, Margarita, Comercio y fraude en el Perú colonial. Las estrategias mercantiles de un banquero, Lima, Instituto de Estudios Peruanos, 1995.

Valle Pavón, Guillermina del, "Los mercaderes de México y la transgresión de los límites al comercio Pacífico en Nueva España, 1550-1620", Revista de Historia Económica, La Economía en tiempos del Quijote, XXIII (Madrid, 2005): 213-240.

Veblen, Thorstein, Teoría de la clase ociosa, México, Fondo de Cultura Económica, 2004.

Yuste, Carmen, El comercio de la Nueva España con Filipinas 1570-1785, México, Instituto Nacional de Antropología e Historia, 1984.

Yuste, Carmen, Emporios transpacificos. Comerciantes mexicanos en Manila 17101815, México, Universidad Nacional Autónoma de México, 2007. 
Yuste, Carmen, "De la libre contratación a las restricciones de la permission. La andadura de los comerciantes de México en los giros iniciales con Manila, 15801610", Salvador Bernabeú y Carlos Martínez Shaw (eds.), Un océano de seda y plata: el universo económico del Galeón de Manila, Sevilla, Consejo Superior de Investigaciones Científicas, 2013: 85-106. Colección Universos Americanos.

Fecha de recepción: 2 de junio de 2014.

Fecha de envío de las modificaciones: 10 de noviembre de 2014.

Fecha de aceptación: 26 de diciembre de 2014.

\section{"Clothing from China" from the Philippines to Buenos Aires. Circulation, consumption and corporate struggle, 1580-1620}

The paper explores the trade and consumption of Asian fabrics that were distributed from Acapulco to Buenos Aires from 1580 to 1620. Our work with primary sources located in the Archivo de Indias, using viceroys', governors' and merchants' reports, prove that 'Ropa de la China" -or clothing from China- was a key element in a trade model that provided an alternative to the official one, with Mexico resisting the economic centralism of Spain.

Key WORDs: trade; consumption; Chinese textiles; Mexico; Rio de La Plata; 1580-1620. 